\title{
Cytotoxicity effects induced by FR91 on human tumour cell lines
}

\author{
V. R. M. Lombardi ${ }^{1}$, E. Martinez ${ }^{2}$, R. Chacon $^{2}$, I. Etcheverria ${ }^{1}$ and R. Cacabelos ${ }^{1}$ \\ ${ }^{1}$ EBIOTEC, Cellular and Molecular Immunology Division, La Coruña, Spain and ${ }^{2}$ Georgian Alternative Medicine, \\ Madrid, Spain
}

Scientific attempts for the in vitro evaluation of natural compounds with biological activity have increased in the last two decades, due mainly to the development of highly automated bioassays screening based on colorimetric methods that can measure the inhibition of proliferation of cell cultures. The main objective of the present work was to evaluate the antiproliferative activity of FR91, a standardized lysate of microbial cells of the Bacillus genus, on human tumour cell lines.

HL-60, H.S. 281.T, H.S. 274.T, H.S. 313.T, SW 982, SW 872, H2126, TOV-21G and WM115 human cell lines were used in the study. All cell cultures were maintained grown as a monolayer, except for HL-60, in DMEM, L-15 and EMEM supplemented with $10 \%$ foetal bovine serum. The cultures were maintained at $37^{\circ} \mathrm{C}$ in a humified $5 \% \mathrm{CO}_{2}$ atmosphere. For tetrazolium-dye (MTT) cytotoxicity assay adherent cell monolayers were trypsinised, washed and plated at 15,000 cells/well in 96 flat bottomed plates. FR91 was added at corresponding wells in duplicate at the concentration of 10, 25 and $50 \mu 1 / \mathrm{w}$, respectively. Untreated cells were used as control. Plates were incubated for $24 \mathrm{~h}$ at $37^{\circ} \mathrm{C}$. After incubation supernatants were removed from all wells and $25 \mu \mathrm{l}$ of MTT solution was added to each well. After $2 \mathrm{~h}$ incubation, $125 \mu \mathrm{l}$ of DMSO was added to the wells and absorbance was read at 450 on a multiwell spectrophotometer. The percentage of cytotoxicity was calculated as $(A-B) / A \times 100$, where $A$ is the mean optical density of untreated wells and $B$ is the optical density of wells treated with FR91.

The results of FR91 activity at the three different concentrations are shown in the table. Values are expressed as percentage of growth inhibition.

According to the results obtained in the study it can be concluded that the FR91 microbial cell lysate shows in vitro antiproliferative activities and that this extract is a good candidate for further activity-monitored fractionation to identify activity principles.

\begin{tabular}{lccr}
\hline Cell lines & $10 \mu \mathrm{l} /$ well & $25 \mu \mathrm{l} /$ well & $50 \mu 1 /$ well \\
\hline HL-60 & 5.8 & 33.5 & 47.1 \\
H.S. 274.T & 1.45 & 2.2 & 2.2 \\
H.S. 313.T & 5.3 & 50.3 & 59.6 \\
SW 872 & 59 & 78.7 & 86.4 \\
SW982 & 51.8 & 72.3 & 87 \\
H2126 & 2.6 & 10.6 & 3.2 \\
TOV-21G & 42.9 & 65.4 & 84.3 \\
WM 115 & 11.3 & 4.1 & 3.1 \\
H.S. 281.T & 4.1 & 3.1 & 0.5 \\
\hline
\end{tabular}

